\title{
İdiopatik İntrauterin Gelişme Geriliği İle Komplike Gebeliklerde Mikroalbuminüri Düzeyinin Araştırılması
}

\author{
Investigation of Microalbuminuria Level in Complex Pregnancies with Idiopathic \\ Intrauterine Growth Retardation
}

Ahmet Berkız TURP

Harran Üniversitesi Tip Fakültesi Kadın Hastalıkları ve Doğum Anabilim Dalı, Şanlıurfa,Türkiye

Geliş Tarihi: 19.06.2019 Kabul Tarihi: 26.01.2020 DOI: 10.17517/ksutfd.580043

Özet

Amaç: Düşük doğum ağırlığı (<2500 g), perinatal mortaliteye, kısa ve uzun dönemde çocukluk çağı morbidite ve mortaliteye ve daha sonraki hayatta ise bir takım kardiyovasküler ve metabolik hastalılara neden olur. Eğer mümkünse Fetal Büyüme sınırlılığı (Fetal Growth Restriction FGR) «nin ve düşük doğum ağırlı̆̆ının önlenmesi klinik ve ekonomik açıdan çok önemlidir. Korunmanın ilk basamağı ise etiyolojiyi anlamaktır.

Gereç ve Yöntemler: Bu bağlamda etiyopatogeneze yönelik endotel disfonksiyonu ve bunun getirdiği sonuçlarda yetersiz trofoblastik invazyonu anlamak için Ekim 2002 ile Temmuz 2004 tarihleri arasındaki Gazi Üniversitesi Tıp Fakültesi Kadın Hastalıkları ve Doğum Anabilim dalı Obstetrik polikliniğinde antenatal takiplerinde FGR saptanan 38 gebe, risk faktörünü bulundurmayıp kontrol grubunu oluşturan rastgele seçilmiş 50 normal gebe olmak üzere toplam 88 olgu çalışmaya dahil edildi. Hastalarda gerek olgu gerekse kontrol grubunda 24 saatlik idrarda mikroalbüminüri düzeyleri karşılaştırıldı. Bu olguların aynı zamanda perinatal sonuçlan da mikroalbüminüri düzeyleri ile karşılaştırıldı.

Bulgular: Çalışmanın sonunda her iki grup karşılaştırıldığında antenatal dönemlerinde mikroalbüminüri açısından gruplar arasında istatiksel bir anlam farkı bulunmadı ( $>0.05)$. Her grupta mikroalbüminüri ile yenidoğan ağırlıkları ile anlamlı bir ilişki bulunmamıştır ( $\mathrm{p}>0.05)$. Sonuç: Sonuç olarak FGR etiyopatogenezinden yetersiz trofoblastik invazyonun değişik mekanizmaların sorumlu olabileceği nedeniyle daha geniş ve kapsamlı araştırmalara gereksinim vardır.

Anahtar Kelimeler: İdiopatik İntrauterin Gelişme Geriliği, mikroalbuminuria,

\footnotetext{
Abstract

Purpose: Individuals who are small at birth are at increased risk of ischemic heart disease and metabolic diseases in their future life. If possible, for clinical and economical point of view, prevention of FGR and low birth weight is crucial. The first step of prevention is the understanding the etiology.

Material and Methods: To understand the etiology of endothelial dysfunction and the results of poor trophoblastic invasion, 88 pregnant women were recruited in this study at Gazi University Hospital Obstetrics and Gynecology Department during October 2002- July 2004. The patients were divided into two groups. These groups were idiopathic fetal growth restriction (FGR) group $(\mathrm{n}=38)$ and control group $(\mathrm{n}=50)$.

Results: Twenty four hour urine specimen were collected to evaluate the microalbuminuria levels of FGR and control groups. Microalbuminuria levels were both compared between FGR and control groups. In addition to that, the perinatal out comes are also correlated with the microalbuminuria levels both in the study and the control group. At the end of the study there was no statistical significance between FGR and control groups microalbuminuria during antenatal period ( $\mathrm{p}>0.05)$.

Conclusion: As a result, different mechanisms might have been responsible for etiology of FGR, further studies and investigations will be necessary.
}

Keywords: Idiopathic intrauterine growth retardation, microalbuminuria

Yazışma Adresi: Ahmet Berkız TURP Harran Üniversitesi Tıp Fakültesi Kadın Hastalıkları ve Doğum Anabilim Dalı, Şanlıurfa Türkiye Mail: bekizus@yahoo.com Tlf: 05303130127

ORCID No: 0000-0003-2981-1096 


\section{GÍRIS}

Normal fetal büyüme embriyodaki hücre proliferasyon, organizasyon ve differansiasyonunun kritik regülasyonu sayesinde gelişir. Bu süreç embriyonun genetik profiline, maternal-plasental-fetal üniteye, gelişen fetusa yeterli besin ve oksijen karşılanması ve fetal ve de maternal hormonal ortam sayesinde olur.

Intrauterin gelişme geriliği (IGG) ile komplike gebeliklerde fetal, maternal ve plasental nedenlerin dişında, olguların yaklaşık \%60'inda altta yatan etiyopatogenez tam olarak aç1ğa kavuşturulmamıştır. Etiyopatogenezi açığa kavuşturulmayan bu gruba idiopatik IUGG denir (1). İdiopatik İUGG’inde trofoblastik hücre disfonksiyonu, buna bağlı olarak plasental yetmezlik ve sonuçta fetal büyüme geriliği oluşmaktadır.

Plasenta, fetal ve maternal dolaşımları arasında bir ara yüzeyi oluşturmakla birlikte maternal-fetal madde alışverişinde de her trimesterde görevi olan bir organdır. Birçok hastalığın plasenta fonksiyonlarını nasıl etkilediği halen çalışmalar yürütülmektedir. Hipertansiyon, obezite, diyabet, otoimmün hastalıklar plasental yetmezliğe neden olabilecek plasental vasküler patolojileri oluştururlar. Plasental yetmezlikte plasental kan akımı ve madde transportunda plasenta düzeyinde yani selüler homeostasis bozulmuştur.

1972 yilında Brosens ve ark. trofoblast invazyonundaki azalma ve plasental yataktaki uteroplasental arterlerdeki gebeliğe spesifik değişikliklerin yokluğunda fetal büyüme geriliğinin ortaya çıktığını göstermişlerdi (2). O zamandan beri endovasküler trofoblastik invazyon plasental araştırmaların en önemli unsuru olmuştur.

Gebelik süresince uteroplasental arterlerde bir takım gebeliğe spesifik değişikleler meydana gelir (3). Bunlar; düz kas endotel ve media tabakasının invaziv trofoblastlar tarafindan değiştirilmesi, elastisite kaybı, kontraktil olmayan geniş tübüller olması, vazomotor kontrol kaybıdır. Genel olarak spiral arter biçiminin değişmesi fetusa yeterli kan akımını sağlamak amacıyla maternal kan akım rezistansında azalmaya ve uteroplasental perfüzyon artışına sebep olur. Plesantal yetmezliğin histolojik temeli endotel orijinli olup vazospazmlar ve mikroanjiopati gibi patolojiler eşlik etmektedir (4).

Endotel tabakası vasküler ve renal fonksiyonların kontrolünde önemli bir role sahiptir. Vasküler tonusu ve permeabiliteyi regüle etmekle beraber koagülasyon ve fibrinoliz dengesini ve de subendotelyal matriks bileşimini lökosit ekstravazasyonunu, vasküler düz kas hücre çoğalmasını regüle eder. Bu fonksiyonların devam edebilmesi için bir takım regülatuar mediatörler mesela nitrik oksid, prostanozoidler, endotelin, angiotensin II, doku tip plazminojen aktivatör ( $t$ PA) ve plazminojen aktivatör inhibitör-1(PAI-1), von Willebrand faktör (vWF), adezyon molekülleri ve sitokinler salar.

Normalde endotel tabakası aktif olarak vasküler tonu azaltır. Besinlere, hormonlara ve makromoleküllere ve lökositlere vasküler permeabiliteyi sağlar (5-6). Buna ek olarak endotel hücreleri trombosit adezyon ve agregasyonunu prostasiklin, nitrik oksit ve koagülasyon kaskadında oluşan trombomodülin- protein $\mathrm{C}$, heparan sülfat- antitrombin III etkileşimi ve t-PA ve onun inhibitörü olan PAI-1 üreterek fibrinolizi regüle eder (7).

İnsanlarda endotel disfonksiyonunu direk olarak ölçen bir metod yoktur. Ancak birtakım medyatörlerin ve regülatuar proteinlerin ölçümü ile endotel disfonksiyonu ortaya çıkarabilir. Bu indirek ölçümler arasında radyoaktif işaretli albuminin transkapiller kaçak hızının hesaplanması, endotelin, von Willebrand factör, trombomodülin, doku-tip plasminojen aktivatörü, plazminojen aktivatör inhibitör-1 'in, soluable E-selektin, soluable VCAM-1 (soluable vasküler hücre adezyon molekülünün) ve selüler fibronektin, tip IV kollajen fragmanların artışı sayılabilir (8-16).

Mikroalbuminüri endotel disfonksiyonunu gösteren bir markırdır (17). Literatürde endoteyal disfonksiyon aterosklerozis ve diabetes mellitus gibi kardiyovasküler hastalıkların etyopatogenezinde rol aldığı gösterilmiştir (18).

$\mathrm{Bu}$ araştırmanın amacı; idiopatik intrauterin gelişme geriliği ile komplike gebeliklerin etyopatogenezininin direk göstergesi olan mikroalbuminüri ile endotelyal disfonksiyon ve buna bağıntılı olarak plasental yetmezlikte bir rolü olup olmadığının araştırılmasıdır.

\section{GEREÇ VE YÖNTEMLER}

Olgu kontrol nitelikte olan çalışma Ankara ilinde Gazi Üniversitesi Tıp Fakültesi Kadın Hastalıkları ve Doğum Anabilim dalı obstetri polikliniğinde Ekim 2002 ile Temmuz 2004 tarihleri arasında tarihleri arasında gerçekleştirilmiştir.

Araştırmanın evrenini, Gazi Üniversitesi Tıp Fakültesi Kadın Hastalıkları ve Doğum Anabilim dalı obstetrik polikliniğinde antenatal takiplerinde intrauterin gelişme geriliği (IUGR) saptanan 50 gebe, risk faktörünü bulundurmayıp kontrol grubunu oluşturan rastgele seçilmiş 50 normal gebe olmak üzere toplam 100 olgu oluşturmuştur. Çalışmaya alınan tüm gebelerin boy ve kiloları ölçülerek vücut kitle indeksi (BMI) hesaplanarak, son adet tarihleri ve USG ölçümleri (BPD, FL, AC, AFI) alınarak gebelik haftaları kesin olarak tespit edilmiştir. Menstrüel siklusları düzensiz olan ve/veya son adet tarihini bilmeyen hastalar için ultrasonografik ölçümler ile belirlenen gestasyonel yaş dikkate alınmıştır. Antenatal takiplerinde riskli gebe polikliniğinde IUGR saptanan (USG ölçümüne göre USG ve diğer ölçüm parametrelerin \%10 persentilin altında olduğu hasta grubu) hastalar seri USG ölçümlerine tabi tutulup umblikal arter Doppler ölçümleri yapılarak umblikal arter S/D oranı 3 üzeri patolojik kabul edilip, amnion sıvı miktarı değerlendirilmesinde $50 \mathrm{~mm}$ altında AFI oligohidroamnios olarak değerlendirilmiştir. Hikayesinde renal hastalık öyküsü bulunanlar, proteinüri olanlar (24 saatlik idrarda $300 \mathrm{mg} /$ gün ve üzeri), mikroalbuminüri düzeyini etkileyebilecek kalp hastalığ 1 , idrar yolu enfeksiyonu veya hematüri olanlar, maternal sistemik hastalık, gestasyonel diyabet, gestasyonel hipertansiyon, çoğul gebelikler, major fetal anomalisi, kromozomal anomalisi 
olan hastalar çalışmaya dahil edilmemiştir. Ayrıca gebelerin antenatal takibi sırasında 24 saatlik idrarda mikroalbuminuri ve kreatinin düzeyine bakılarak mikro albuminuri düzeyi 28 ile 36 haftalar arasında sabah saat 8'den ertesi gün sabah saat 8'e kadar 24 saat idrar örneklerinde değerlendirilmiştir. Ölçüm 24 saat içerisinde toplanan idrar hacminin ölçülmesini takiben 10cc kadar idrar örneği alınarak Gazi Üniversitesi İmmunoloji Anabilim Dalı tarafından üretilen Monoklonal bazlı House-Elisa yöntemi ile çalışıldı.

Verilerin bilgisayar ortamında SPSS (Statistical Package for Social Sciences) 11.5 paket programı kullanılarak, frekans, ortalama, $\mathrm{Ki}$ - kare testi ( $\chi 2$ 2) testleri ile analiz edilmiştir. Veriler \%95 güven aralığında anlamlılıklar $\mathrm{p}<0.05$ düzeyinde olacak şekilde değerlendirilmiştir. Araştırma için Gazi Üniversitesi Tıp Fakültesinden yazılı izin alınmış ve izin yazısı Gazi Üniversitesi Tıp Fakültesi etik kuruluna başvurulmuştur. Gerekli etik kurul izini alındıktan sonra çalışmaya başlanmıştır. Katılımcılara araştırma hakkında bilgi verilmiş, formdan elde edilen bilgilerinin ismen deşifre edilmeyeceği belirtilerek, aydınlanmış onam formu imzalattırılmıştır.

\section{BULGULAR}

Olgular materyal ve metot bölümünde belirtilen özelliklere göre FGR \%43.2 (38 kişi), ve kontrol grubu \%56.8 (50 kişi) olmak üzere iki gruba ayrıldı. Antenatal takibi süresince herhangi bir gebelik komplikasyonu saptanmayan olgular kontrol grubu olarak alınmıştır. Tablo 1'de görüldüğü gibi; maternal yaş dağılımı 21-36, maternal ağırlık dağılımı 44-80 kg, maternal BMI dağılımı 19.31-28.93 kg/men , yenidoğan ağırlık dağılımı 1518-4080 gr, doğum haftası dağılımı 33-41 hafta 6 gün, 1.dk APGAR dağılımı 5-10, 5.dk APGAR dağılımı 8-10 olarak saptanmıştır.

\section{Tablo 1. FGR ve kontrol gruplarının özellikleri} (ortalama \pm standart sapma)

\begin{tabular}{|l|c|c|c|}
\hline & $\begin{array}{c}\text { FGR } \\
\mathbf{N = 3 8}\end{array}$ & $\begin{array}{c}\text { Kontrol } \\
\mathbf{N = 5 0}\end{array}$ & $\mathbf{p}$ \\
\hline Maternal yaş (y1l) & $28.5 \pm 3.6$ & $28.3 \pm 4.1$ & 0.760 \\
\hline $\begin{array}{l}\text { Maternal ağırlık } \\
(\mathrm{kg})\end{array}$ & $67.5 \pm 7.0$ & $69.3 \pm 4.9$ & 0.144 \\
\hline $\begin{array}{l}\text { Maternal BMI } \\
\text { (kg/m2) }\end{array}$ & $23.9 \pm 1.8$ & $24.7 \pm 1.7$ & $0.042^{*}$ \\
\hline $\begin{array}{l}\text { Yenidoğan } \\
\text { ağırlığ1 (g) }\end{array}$ & $2277.8 \pm 238.7$ & $3327 \pm 356.6$ & 0.144 \\
\hline Doğum haftas1 & $36.9 \pm 1.2$ & $39.1 \pm 1.0$ & $0.001^{*}$ \\
\hline APGAR 1.Dk & $7.76 \pm 1.7$ & $9.74 \pm 0.56$ & $0.001^{*}$ \\
\hline APGAR 5.Dk & $9.57 \pm 0.82$ & $10.0 \pm 8.8$ & $0.001^{*}$ \\
\hline $\begin{array}{l}\text { Kreatinin klerensi } \\
\text { (ml/dk) }\end{array}$ & $98.1 \pm 10.59$ & $100.5 \pm 8.87$ & 0.247 \\
\hline
\end{tabular}

${ }^{\star}$ Independent t-testi, $\mathrm{p}<0.05$ istatiksel anlamlı farklılık.

Hastaların 48'i (\%54.5) nullipar ve 40’1 (\%45.5) multipar olarak saptanmıștır. FGR grubunda doğumların 13’ü
(\%34.21) normal spontan vajinal yolla, 25’i (\%65.79) sezaryenle gerçekleşirken, kontrol grubunda ise gebelerin 35 'i (\%70) normal spontan vajinal yolla, 15'i (\%30) sezaryenle doğum yapmiştır.

Çalışmaya alınan hastaların yaşları FGR grubunda 28.5 \pm 3.6 , kontrol grubunda ise 28.3 \pm 4 .1 olarak saptanmıştır ( $>0.05)$. FGR olan grupta doğumda tahmini gebelik haftası 36.9 \pm 1.2 , kontrol grubunda $39.1 \pm 1.0$ hafta idi. Çalışma ve kontrol gruplarında ortalamaları arasında istatiksel olarak anlamlı fark vardir $(\mathrm{p}<0.001)$.

FGR grubunun maternal ortalama ağırlıkları $67.5 \pm 7.0 \mathrm{~kg}$, kontrol grubunun maternal ortalama ağırlıkları $69.3 \pm 4.9 \mathrm{~kg}$ olarak saptanmıştır. Çalışma ve kontrol grubunun maternal ağırlıkları arasında istatiksel olarak anlamlı fark saptanmamiştır ( $\mathrm{p}>0.05)$.

FGR grubunun ortalama maternal BMI değerleri $23.9 \pm 1.8 \mathrm{~kg} / \mathrm{m}_{2}$, kontrol grubunun ortalama maternal BMI değerleri $24.7 \pm 1.7 \mathrm{~kg} / \mathrm{m}_{2}$ olarak saptanmıştır. Çalışma ve kontrol gruplarının ortalama maternal BMI değerleri arasında istatiksel olarak sınırda anlamlı çıkmıştır ( $p=0.042)$. Bu fark çalışmamızı etkileyecek kadar anlamlı bulunmamıştır.

FGR olgularındaki bebeklerinin 1.dk ortalama APGAR skorlar1 7.76 \pm 1.7 , kontrol grubunun ise olarak 9.74 \pm 0.56 olarak bulunmuştur. Çalışma gruplarının APGAR skorları kontrol gruplarına göre istatistiksel olarak anlamlı bulunmuştur $(\mathrm{p}<0.001)$.

FGR olan olgularin bebeklerinin 5.dk ortalama APGAR skorlar1 9.57 \pm 0.82 , kontrol grubunun ise olarak $10.0 \pm 8.8$ olarak bulunmuştur. Çalışma gruplarının APGAR skorları kontrol gruplarına göre istatistiksel olarak anlamlı bulunmuştur $(\mathrm{p}<0.001)$.

Doğum ağırlıkları incelendiğinde FGR olan olguların ortalama doğum ağırlığı 2277.8 \pm 238.7 g iken, kontrol grubunda ortalama doğum ağırlığı ise $3327 \pm 356.6$ g olarak bulunmuştur. FGR grubunun ortalama doğum ağırlı̆̆ kontrol grubuna istatistiksel olarak anlamlı fark saptanmamıştır ( $p>0.05)$. FGR grubunda olan hastaların ortalama kreatinin klerensi $98.1 \pm 10.59 \mathrm{ml} / \mathrm{dk}$ iken, kontrol grubunun ortalama kreatinin klerensi $100.5 \pm 8.87$ olarak bulunmuştur. Her iki grup arasında istatiksel olarak anlamlı fark saptanmamıştır $(\mathrm{p}>0.05)$.

Tablo 2. Kontrol ve FGR gruplarının proteinüri miktarları

\begin{tabular}{|l|c|c|c|}
\hline & $\begin{array}{c}\text { FGR } \\
\mathbf{N = 3 8}\end{array}$ & $\begin{array}{c}\text { Kontrol } \\
\mathbf{N = 5 0}\end{array}$ & p \\
\hline $\begin{array}{l}\text { Mikroalbüminüri hızları } \\
(\mu \mathrm{g} / \mathrm{dk})\end{array}$ & $28.4 \pm 30.7$ & $21.2 \pm 18.8$ & 0.180 \\
\hline $\begin{array}{l}\text { Yirmidört saatlik idrarda } \\
\text { protein miktarı (mg/gün) }\end{array}$ & $41.0 \pm 7.2$ & $30.7 \pm 3.8$ & 0.180 \\
\hline
\end{tabular}


Tablo 2'de görüldüğü gibi; FGR ve kontrol gruplarının 24 saatlik idrar örneklerinde protein atılım miktarları veril-

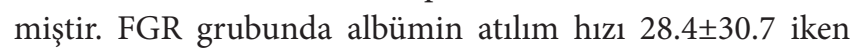
kontrol grubunda ise $21.2 \pm 18.8$ olarak bulunmuştur. Albümin atılım hızı için her iki grup arasında istatiksel olarak anlamlı bir fark saptanmamıştır ( $p>0.05)$. FGR ve kontrol gruplarını 24 saatlik idrar örneklerinde protein miktarları verilmiştir. FGR grubunda 24 saatlik idrarda protein miktar1 $41.0 \pm 7.2 \mathrm{mg} /$ gün iken kontrol grubunda ise $30.7 \pm 3.8 \mathrm{mg} /$ gün olarak bulunmuştur. 24 saatlik idrarda protein miktarı için her iki grup arasında istatiksel olarak anlamlı bir fark saptanmamıştır ( $\mathrm{p}>0.05)$.

Tüm grupta normal albümin atılımı olan olgu sayısı 57 $(\% 64,8)$ iken mikroalbüminüri seviyesinde olan olgu sayısı 31 (\%35.2) olarak saptanmıştır. Bu tablonun şematik bir şekli ise Şekil 1'de belirtilmiştir.

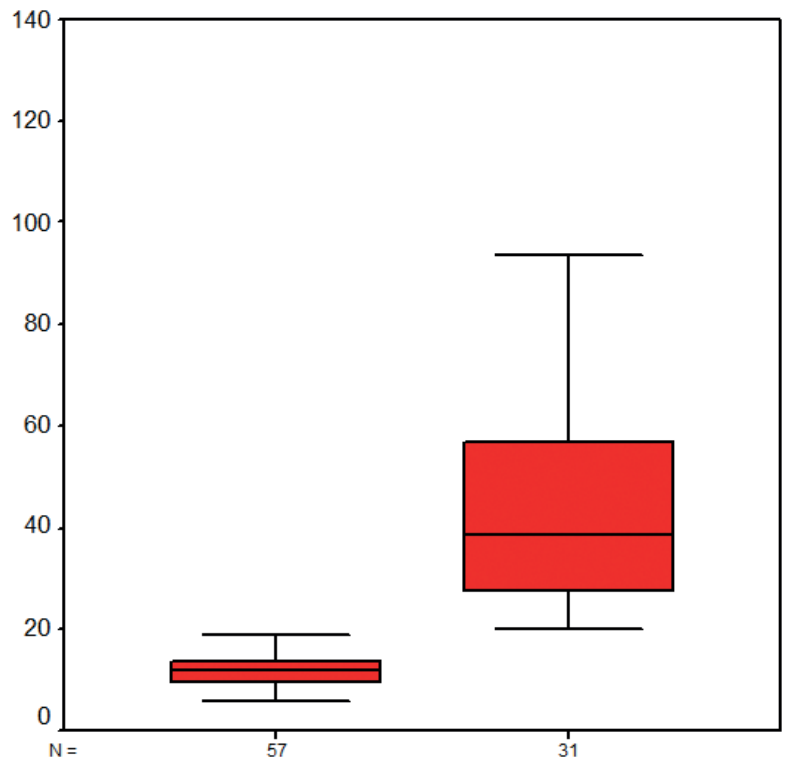

Şekil 1. FGR ve kontrol grubunda mikroalbüminüri saptanan olguların dağılımı

\section{TARTIŞMA}

Farklı klinik, biyofiziksel ve biyokimyasal testlerle gebelikte istenmeyen sonuçları öngörmeye yönelik çeşitli çalışmalar yapılmıştır. FGR obstetrikte önemli perinatal morbidite ve mortalite nedenleri arasındadır. Fetal ölüm, doğum asfiksisi, mekonyum aspirasyonu ve neonatal hipoglisemi ve bunların sonucunda da anormal nörolojik gelişim prevalansı artmaktadır (19). Bu fenomen aynı zamanda term ve preterm yenidoğanlar için de geçerlidir (20). Eğer büyüme geriliği plasental yetmezliğe bağlı ise genellikle büyüme potansiyellerini yakalamaktadırlar. Benzer olarak büyüme geriliği saptanan fetüslerin nörolojik gelişimi prenatal ve postnatal çevreye bağlıdır. İyi sosyoekonomik statüye sahip ailelerin yeni doğanlarında bu bağlamda daha az gelişme problemleri görülmektedir.
FGR'nin patofizyolojisi; maternal besin deposunun yeterliliğine, fetoplasental etkileşime ve fetomaternal adaptasyona dayanır. Bir çalışmada terme doğru gidildikçe uterin kan akımının arttığı ve vasküler rezistansın azaldığı ortaya konulmuştur (21). Yeterli plasentasyon varlığında, plasental kan akımı tüm fetal ihtiyaçları karşılarken, plasentasyonda bir defekt var ise veya plasental kan akımı yeterli değilse, FGR veya intrauterin fetal ölüm meydana gelebilmektedir (22). Fetal büyümede birçok faktör rol oynasa da günümüzde fetal büyümenin tam olarak selüler ve moleküler mekanizmaları açığa kavuşturulamamıştır. Erken fetal dönemde büyümeyi belirleyen ana faktör fetal genlerdir. İleri haftalarda çevresel, beslenme ve hormonal faktörler önem kazanır (23).

Gebeliğin ilk yarısında uteroplasental arterler bir takım gebeliğe spesifik değişikliklere uğrarlar. Bunlar endotel-media tabakasındaki düz kas hücrelerinin yerini invaziv trofoblastların alması, elastisite kaybı, geniş kontraktil olmayan tübüllere dönüşüm ve vazomotor kontrol kaybıdır (10). Bu çalışmaların sonunda endovasküler trofoblastik invazyon yetersizliği FGR'nin son yıllarda kabul görmüş olan etiyolojik faktörüdür. Endotel hücre aktivasyonu yetersiz trofoblastik invazyon ve bunu sonucunda da plasental yetmezliğin bir sonucu olan fetal büyüme geriliğine yol açar (24). Johnson ve ark.'nın yaptığı çalışmada endotelyal hücre aktivasyonuna bağlı VCAM, ICAM ve e-selektin gibi adezyon moleküllerinin artışını preeklampsi ve FGR gibi yetersiz plasentasyonda göstermişlerdir (24). İşte FGR patofizyolojisinde bu uteroplasental arterlerdeki "remodelling"deki yetersizliğe bağlıdır.

Fetal büyüme geriliği bağlamında erişkin hipertansiyon ve aterosklerozis riskinin artışı suboptimal fetal beslenme ile ilişkisi ile ilgili tezler savunulmuştur. Literatürdeki son yayınlar ise bu hipotezleri desteklemektedir. Günümüzde ateroskleroz ve metabolik sendrom ismiyle adlandırılan sistemik hastalıklar en önemli morbidite ve mortalite nedenlerini oluşturmaktadır. Bu dönemde yapılan en büyük çalışmalar bu hastalıkların biyolojisini ve eşlik eden risk faktörlerini ortaya çıkarmaktadır.

Mikroalbüminüri ve gebelik ile yapılan kısıtlı sayıdaki çalışmalar mikroalbüminin prevalansı ve kardiyovasküler hastalıklar için risk faktörlerini araştırmak amacıyla yapılmıştır. Genelde mikroalbüminüri, bir belirteç ve tarama aracı olarak gebeliğe bağlı hipertansiyonu araştırmak, onu önceden saptamak ve mikroalbüminüri saptanan bu hastaları dikkatlice değerlendirmek amacıyla araştırılmıştır.

Literatürdeki farklı bir çalışma olan Singh H ve ark'nın çalışmasında fetal komplikasyonların mikroalbüminürili gebelerin bebekleri ile daha fazla ilişkili olduğu bulunmuştur (25).

Ekbom ve ark.'nın yaptığı diğer bir çalışmada mikroalbüminürinin Tip 1 Diabetes ile komplike olan gebelerde gebelik sonuçlarını etkileyip etkilemediği tartışılmıştır (26). Çalışmada mikroalbüminürik düzeyde albümin atılımı olan gebelerde preterm eylem ve preeklampsinin daha sıklıkta görüldüğü saptanmıştır. Aynı zamanda diabetik nefropatili ka- 
dınlarda intrauterin büyüme geriliği artarken mikroalbüminüri düzeyinde albümin atılım hızı olan gebelerde FGR insidansında bir artış saptanmamıştır. Bu sonuç idiopatik FGR ile komplike gebelerin etiyopatogenezinde mikroalbüminüri olmadığı; çalışmamızın sonuçları ile paralel olduğu şeklindedir. Sonuç olarak mikroalbüminürili gebelerde prematür doğum prevalasında artış saptandığı ve bunun da preeklampsiye sekonder olduğu yorumuna varılmıştır (26).

Schröder ve ark.'nın yaptığı çalışmada insülin ile tedavi edilen diabetik gebelerde mikroalbüminüri önceden saptanabilen bir risk faktörü olarak saptanmıştır (27). Çalışmada tüm hasta grubunda, mikroalbüminüri saptananlarda gebeliğe bağlı hipertansiyon insidansında artış olduğu saptanmıştır. Fakat yapılan diğer çalışmalarla beraber yazarlar hipergliseminin glomerüler kapiller bazal membranında ve mezangial matriksin içeriğinde ve endotelyal disfonksiyon sonucunda değişiklikler yaparak bu hadisenin oluşmasında rol oynadığını belirtmişlerdir (27).

Preterm doğumların geniş etiyolojisini düşünecek olursak sistemik hasarın bir göstergesi olan mikroalbüminüri preterm doğum için bir belirteç olarak literatürde araştırılmıştır. Masse ve ark.'nın yaptığı 1442 gebeyi kapsayan bir kohort çalışmasında preterm doğumlarda mikroalbüminürinin iyi bir belirteç olmadığı saptanmıştır (28).

Tüm literatür mikroalbüminüri ile yapılan çalışmalar için özetlenecek olursa gebeliğe bağlı hipertansiyonun tahmin etmede mikroalbüminüri düzeyi araştırılması yararlı olduğu söylenebilir. Özellikle diabetik gebelerde düşük ve yüksek riskli olan hastaları kategorize etmede ve antenatal takiplerinin hangi sıklıkta yapılacağı açısından mikroalbüminüri düzeyi araştırılması yararlı olduğu gösterilmiştir (27).

Literatürdeki çalışmalardan biri de Smith ve ark.'nın düşük doğum ağırlığı ile doğum yapmış annelerin daha sonraki hayatlarında iskemik kalp hastalığı riskinin artmış olduğu saptanmasıdır (29). Burada düşük doğum ağırlığı ve kalp hastalığı riski anne ve gelişen fetüs için bir genetik risk oluşturacağını savunmuşlardır. Çalışmada $2500 \mathrm{~g}$ ve altında doğum ağırlığında doğum yapanlarda, 3500 g ve üstü doğum ağırlığında doğum yapanlara göre iskemik kalp hastalığına bağlı ölüm riski 11 kat daha fazla bulunduğu ortaya çıkmıştır (29).

Bu bilgilerden yola çıkarak kardiyovasküler morbidite ve mortalitedeki artışı gerek fetüs gerekse maternal iskemik kalp hastalıklarından korunmada erken göstergesi olabileceği bir belirteç olan mikroalbüminüriyi araştırmak bundan sonraki çalışmalara ışık tutacaktır.

Çalışmamızda savunduğumuz hipotezde FGR ile komplike olan gebelerin etiyopatogenezinde maternal endotelial disfonksiyon ile gelişen sekonder yetersiz trofoblastik invazyona ve bunun sonucunda da anormal plasentasyon olabileceğini göstermeyi amaçladık. Çalışmamızın eksik yönlerinden birisi de bu anormal plasentasyonu patolojik olarak saptayamadik.
Endotelyal disfonksiyonun erken ve önemli göstergelerinden biri olan mikroalbüminüri düzeyinde albümin atılım hızını ölçtük. Olgu grupları ve kontrol grupları karşılaştırıldığında mikroalbüminüri düzeyleri bakımından istatiksel bir farkın olmadığını saptadık ( $p>0.05)$. Bu da idiopatik FGR'nin etiyopatogenezinde yaygın sistemik bir hasarın ilk göstergelerinden mikroalbüminüri seviyesinin yeterli bir belirteç olmadığını gösterdi. Asıl sorun böyle bir belirtecin yaygın olarak komplike gebeliklerde kullanılıp kullanılmamasıdır. Literatürde mikroalbüminüri ile yapılan çelişkili birçok araştırma vardır. Bir kısım yazar mikroalbüminürinin preterm eylem için önemli bir belirteç olmasından (26) bahsederken, diğer yazarlar bu tür komplike gebeliklerde mikroalbüminüri taramanın hiçbir faydası olmadığından söz etmektedirler (28). Bizim sonuçlarımız FGR ile komplike gebeliklerde literatür ile paraleldir. Daha önceden belirtildiği gibi Schroder ve ark. preeklampsinin mikroalbüminüri ile birlikteliliğinden söz ederken FGR ile hiçbir korelasyon bulamamıştır (27).

Yapılan tüm çalışmalarda mikroalbüminüri ile FGR ile direk ilişki olmayıp bunun özellikle gebeliğin bir komplikasyonu olan preklampsiye sekonder bir bulgu olduğudur. Literatürdeki albümin atılım hızı ile FGR arasındaki ilişkiyi gösteren çalışmada aşikar proteinüriye sahip olan diabetik nefropatili gebelerde FGR saptanmasıdır. FGR ve kontrol grubunda bakılan 24 saatlik albümin atılım hızı bakımından gerek FGR gerekse kontrol grubunda normal albümin at1lım hızı ile mikroalbüminüri düzeyleri arasında istatistiksel olarak anlamlı değişiklik saptanmamıştır ( $\mathrm{p}>0.05)$. Tüm olgularda mikroalbüminürik seviyede albümin atlım hızı olan olguların yenidoğan özelliklerinden doğum ağırlığı, 1. dakika APGAR ve 5. dakika APGAR seviyeleri normal albümin atılım hızı olan olgularla da karşılaştırılmıştır. Bu bağlamda her iki grup arasında istatiksel olarak anlamlı ilişki saptanmamıştır.

Çalışmamızda aşikâr proteinüri atılımına sahip olan hastalar çalışma kapsamının dışında olduğu için ilişkiyi bu açıdan gösteremedik.

Komplike olmayan hamilelik sırasında proteinüri gelişmesi kötü prognostik işaret olarak kabul edilir ve maternal, perinatal morbidite ve mortaliteyi artırır. Kötü obstetrik hikaye belirlenirken mikroalbüminüri ölçümünün önemi ile ilgili çelişkili sonuçlar bulunmuştur.

Sonuç olarak; Hızlı, ucuz ve basit olan mikroalbüminüri ölçümünün yararı ve iyi kanıtlar bulmak için idiopatik gelişme geriliği tanısı almış olan hastalarda daha fazla araştırma yapılması gerekir, bu sayede riskli kadınlarda tanımlanabiliriz ve buna göre yönetilebiliriz.

Çıkar çatışması ve finansman beyanı: Bu çalışmada çıkar çatışması yoktur ve finansman desteği alınmamıştır. 


\section{KAYNAKLAR}

1. Ghidini A. Idiopathic fetal growth restriction: a pathophysiological approach. Obstet Gynecol Surv 1996;51(6):376-382

2. Brosens IA, Robertson WB, Dixon HG. The role of the spiral arteries in thepathogenesis of preeclampsia. Obstet Gynecol Annu 1972;1:177-191

3. Kaufman P, Black S, Huppertz B. Endovascular Trophoblast Invasion: Implications for the Pathogenesis of Intrauterine Growth Retardation and Preeclampsia Biology of Reproducion 2003;69:1-7

4. Dekker GA. Sibai BM. Low- dose aspirin in the prevention of pre-eclampsia and fetal growth retardation: rationale, mechanisms and clinical trials. Am J Obstet Gynecol 1993;168:214227

5. Renkin EM. Capillary transport of macromolecules: pores and other endothelial pathways. J Appl Physiol 1985;58:315-325

6. Pober JS, Cotran RS. Cytokines and endothelial cell biology. Physiol Rev 1990;70:427-451

7. vanHinsbergh VWM, ed. Vascular Control of Hemostasis. Advances in Vascular Biology Vadas MA, Harlan J, serieseds.., Voll. Amsterdam: Harwood Academic Publishers, 1996

8. Stehouwer CDA. Von Willebrand factor, dysfunction of the vascular endothelium, and the development of renal and vascular complications in diabetes. In: Mogensen CE, ed. The Kidney and Hypertension in Diabetes Mellitus, 3rd edn. Boston: Kluwer, 1997:155-163

9. Stehouwer CDA, Donker AJM. Urinary albumin excretion and cardiovascular disease risk in diabetes mellitus: Is endothelial dysfunction the missing link? J Nephrol 1993;6:72-92

10. Vane JR, Anggård EE, Botting RM. Mechanisms of disease: regulatory functions of thevascular endothelium. N Engl J Med 1990;323:27-36.

11. Hamsten A. Hemostatic function and coronary artery disease. N Engl J Med 1995;332:677-678

12. Jansson JH, Nilsson TK, Johnson O. Von Willebrand factor in plasma: a novel risk factor for recurrent myocardial infarction and death. BrHeart J 1991;66:351-355

13. Ridker PM, Vaughan DE, Stampfer MJ, Manson JE, Hennekens $\mathrm{CH}$. Endogenous tissue-type plasminogen activator and risk of myocardial infarction. Lancet 1993;341:1165-1168

14. Omland T, Lie RT, Aakvaag A, Aarsland T, Dickstein K. Plasma endothelin determination as a prognostic indicator of 1 -year mortality after acute myocardial infarction. Circulation 1994;89:1573-1579

15. Thompson SG, Kienast J, Pyke SD, Haverkate F, van de Loo JC. Hemostatic factors and the risk of myocardial infarction or sudden death in patients with angina pectoris. N Engl J Med 1995;332:635-641

16. Blann AD, Taberner DA. A reliable marker of endothelial dysfunction: does it exist? Br J Haematol 1995;90:244-248

17. Waldron JS, Baoku Y, Hartland AJ, Anderson NR, Horton R, Gama R. Urine microalbumin excretion in relation to exercise-induced electrocardiographic myocardial ischaemia. Med Sci Monit, 2002;8(11):725-727

18. Ross R. The pathogenesis of atherosclerosis: A perspective for the 1990s. Nature 1993;362:801-809

19. Stehouwer CDA, Donker AJM. Clinical usefulness of measurement of urinary albumin excretion in diabetes mellitus. Neth J Med 1993;42:175-186

20. Severi FM, Bocchi C, Visentin A, Falco P, Cobellis L, Florio P, et al. Uterine and fetal cerebral Doppler predict the outcome of third-trimester small-for-gestational age fetuses with normal umbilical artery Doppler. Ultra Obstet Gynecol 2002;19:225228

21. Kaufmann P, Black S, Huppertz B. Endovascular trophoblast invasion: implications for the pathogenesis of intrauterine growth retardation and preeclampsia. Biol Reprod 2003;69:1-7

22. Pober JS, Cotran RS. Cytokines and endothelial cell biology. Physiol Rev 1990;70:427-451

23. Lapillonne A, Peretti N, Ho PS, Claris O, Salle BL. Aetiology, morphologyand body composition of infantsbornsmallforgestational age. Acta Paediatr 1997;423:173-173

24. Masse J, Forest JC, Moutquin JM. Microalbumin as a marker of premature delivery. Obstet Gynecol 1996;87:661-663

25. Singh H, Samal S, Mahapatro A, Ghose S. Comparison of obstetric outcome in pregnant women with and without microalbuminuria. J Nat Sci Biol Med. 2015;6(1):120-4

26. Ekbom P, Damm P, Feldt-Rasmussen B, Feldt-Rasmussen U, Molvig J, Mathiesen ER. Pregnancy outcome in type 1 diabetic women with microalbuminuria. Diabetes Care 2001;24:17391744

27. Schroder W, Heyl W, Hill-Grasshoff B, Rath W. Clinical value of detecting microalbuminuria as a risk factor for pregnancy-induced hypertension in insulin-treated diabetic pregnancies Euro Jour Obstet Gynecol Reprod Bio 2000;91:155-158

28. Masse J, Forest JC, Moutquin JM. Microalbumin as a marker of premature delivery. Obstet Gynecol 1996;87:661-663

29. Smith GC, Pell JP, Walsh D. Pregnancy complications and maternal risk of ischaemicheartdisease: a retrospective cohort study of 129.290 births. Lancet 2001;357: 2002-2006 